\title{
Seasonal Dynamics in Air Quality Index and its Role in Pollution Mapping
}

\author{
A. Verma and S.N. Singh* \\ Environmental Science Division, \\ CSIR-National Botanical Research Institute, Lucknow - 226 001, (U. P.) India
}

\begin{abstract}
Alteration pattern of Air Quality Index with changing seasons, was studied and air monitoring was carried out at different road intersections selected in the trans-Gomti, central and southern regions of the Lucknow city. On the basis of levels of different pollutants in the ambience, the Air Quality Index was calculated to categorize the sites from very clean to polluted range. The air Quality Index data showed that the central region of the city was maximally polluted with auto-exhaust emission, followed by trans-Gomti region, while the southern region was minimally polluted. A marked seasonal variation pattern was also observed in the AQI being maximum in the winter season, followed by summer and the least in the rainy season. With the help of AQI, a pollution map of Lucknow city was prepared for the first time with different colour shades indicating the levels of air pollution in different localities.
\end{abstract}

Keywords: Air pollution map, Air quality index, Ambient pollutants, Temporal variations.

\section{Introduction}

Air pollution caused by motor vehicles is indeed a serious problem in major cities. This problem is rapidly growing with increasing number of vehicles on the roads. The incessantly increasing size of urban areas in India and haphazard growth of work places and residential areas in large cities need more and longer commution trips. The growing situation results in higher energy consumption and also higher emission of air pollutants by vehicles. Inadequate attention has been given so far to public transportation in India, which has resulted in a dramatic growth of private vehicles, causing more environmental problems. In Lucknow city alone, the vehicular population has augmented many folds in recent years. It was 0.38 million in 1998 and has now exceeded 0.6 million in 2003. In most urban centres, private mode of transportation, unfortunately, continues to form the predominant transport system. This situation is likely to subsist for a number of years to come, giving rise to traffic congestion, higher energy costs and alarming atmospheric pollution, unless we strengthen the public transport facilities.About the vehicular pollution, the expert committees report of World Health Organization (WHO, 1969) has specially mentioned the case of India that while the vehicular population in India may be small as compared to those in more advanced western nations, the environmental pollution problem is quite formidable due to a predominance of old and poorly maintained vehicles, narrow roads, poor technology and high weight and H.P. ratio.

Most common air pollutants in the urban environment are sulfur dioxide, nitrogen dioxide carbon monoxide, suspended particulate matter (SPM) and ozone (D'Amato, 1999). Out of which, SPM is of greatest concern, as it contributes $50 \%$ to total air pollution load (Fuller, 1974) and causes respiratory disorders in human beings on prolonged exposure. A few sporadic studies have been carried out on the assessment of air quality in different cities. Joshi (1998) carried out the monitoring of respirable suspended particulate matter (RSPM) 
and total suspended particulate matter (TSPM) in the core city area of Indore (Madhya Pradesh, India) and found higher RSPM and TSPM levels at about all the selected road intersections as compared to the prescribed standards of CPCB, New Delhi. $\mathrm{NO}_{2}$ and $\mathrm{SO}_{2}$ are the two primary gaseous pollutants, which also contribute to acidic deposition in terrestrial ecosystem as dry deposited gases or in dissolved form in precipitation (Cox, 2003). In aerosol form, they also impact visibility. $\mathrm{NO}_{2}$, on the other hand is a precursor for the formation of photochemical oxidants, which directly affect human health (Aneja et al., 2001). Sivacoumar et al. (2001) carried out the NOx monitoring at Jamshedpur - an industrial city of Jharkhand state and concluded that the industries contributed $53 \%$, domestic sources about $7 \%$, while automobile accounted for $40 \%$ of NOx pollution in the region. In another study conducted by Samanta et al. (1998), air monitoring of Calcutta city was carried out for different air pollutants and was compared with those of important cities of the India and world. It was observed that the pollution level of Calcutta was much higher than that of WHO limits and was also much greater than other metro cities of India and world. Similarly, the results of a study, carried out by Chaaban et al. (2001) at Beirut, Lebanon, revealed the seriousness of air pollution problem in the city. Gaseous pollutants, such as $\mathrm{SO}_{2}, \mathrm{NO}_{2}$ and $\mathrm{O}_{3}$, have detrimental effects of varying magnitude on wheat, mustard, mung and palak plants depending upon individuals pollutant concentration, in combination, plant species and seasons (Agrawal et al., 2003).

Air quality index (AQI) is an indexing system developed to assess the air quality in different localities. This tool is used to inform the public about air pollution levels in a particular location, and its associated health effects. This helps the government to take remedial measures well in time when the air pollution reaches alarming levels in a locality or region. The study was carried out with the objective to observe the changes in AQI with changing seasons and also to demonstrate the role of AQI in pollution mapping of any city or industrial agglomeration.

\section{Materials and Methods}

The Lucknow city is situated between $26^{\circ} 52^{\prime} \mathrm{N}$ latitude and $80^{\circ} 56^{\prime} \mathrm{E}$ longitude and $120 \mathrm{~m}$ above the sea level in the central plain of the Indian sub-continent. It is the capital of Uttar Pradesh and one of the largest and highly populous states of India. The city area is spread over an area of $79 \mathrm{~km}^{2}$ and has a population of more than 1.7 million. It has distinct tropical climate with a marked monsoonal effect. The year is divided into 3 distinct seasons i.e. summer (March to June), rainy (July to October) and winter (November to February). The temperature ranges from a minimum of $5^{\circ} \mathrm{C}$ in winter to a maximum of $45^{\circ} \mathrm{C}$ in summer. The mean average relative humidity is $60 \%$ and rainfall $100.68 \mathrm{~mm}$. The meteorological data of the study site during measurement period have been presented in Table 1.

In order to evaluate the present status of the ambient air quality of Lucknow city, the whole city was divided in to three geographical regions i.e. trans-Gomti, central and southern regions. In each region, different road intersections, representing low to high traffic density, were selected for the purpose of air monitoring in different seasons. In the trans-Gomti region, 12 sites were selected as Kukrail forest picnic spot, Chhanilal crossing, HAL crossing, Gomti nagar police station intersection, Badshah nagar intersection, Vikas nagar intersection, Engineering college crossing, Picup bhawan intersection, Purania crossing, Munshipulia crossing, Sitapur road intersection and IT crossing and designated as $\mathrm{T} 1, \mathrm{~T} 2, \mathrm{~T} 3, \mathrm{~T} 4, \mathrm{~T} 5$, $\mathrm{T} 6, \mathrm{~T} 7, \mathrm{~T} 8, \mathrm{~T} 9, \mathrm{~T} 10, \mathrm{~T} 11$ and $\mathrm{T} 12$, respectively for convenience. Likewise, in the central region also, 10 road intersections were selected as National Botanical Garden, Jopling road intersection, Aishbagh crossing, Aminabad crossing, Medical college crossing, Charbagh crossing, Kaiserbagh crossing, Hussainganj crossing, Hazaratganj crossing, and Parivartan square and identified as C1, C2, C3, C4, C5, C6, C7, C8, C9 and C10, respectively. Similarly, Ashiyana intersection, Sadar crossing, 
Table 1 Metrological conditions of Lucknow city during the study period.

\begin{tabular}{|c|c|c|c|c|}
\hline \multirow{2}{*}{ Month } & \multicolumn{2}{|c|}{ Mean temperature ${ }^{\circ} \mathrm{C}$} & \multirow{2}{*}{$\begin{array}{l}\text { Mean } \\
\text { total } \\
\text { rainfall } \\
(\mathrm{mm})\end{array}$} & \multirow{2}{*}{$\begin{array}{l}\text { Mean } \\
\text { number } \\
\text { of rainy } \\
\text { days }\end{array}$} \\
\hline & $\begin{array}{c}\text { Daily } \\
\text { minimum }\end{array}$ & $\begin{array}{c}\text { Daily } \\
\text { maximum }\end{array}$ & & \\
\hline January & 6.9 & 22.6 & 21.9 & 1.6 \\
\hline February & 9.3 & 26.0 & 11.2 & 1.1 \\
\hline March & 14.2 & 32.2 & 7.7 & 0.7 \\
\hline April & 20.5 & 38.1 & 4.9 & 0.5 \\
\hline May & 24.7 & 40.5 & 16.5 & 1.0 \\
\hline June & 27.1 & 38.7 & 107.4 & 4.2 \\
\hline July & 26.1 & 33.6 & 294.3 & 11.6 \\
\hline August & 25.6 & 32.5 & 313.9 & 13.1 \\
\hline September & 24.3 & 33.0 & 180.6 & 7.4 \\
\hline October & 19.0 & 32.5 & 45.2 & 2.0 \\
\hline November & 11.8 & 28.9 & 3.8 & 0.3 \\
\hline December & 7.4 & 24.1 & 7.3 & 0.7 \\
\hline
\end{tabular}

Anand nagar crossing, Telibagh crossing, Cantt road intersection and Alambagh crossing were selected as sites in southern region for air pollution monitoring. These sites were designed as $\mathbf{S 1}, \mathrm{S2}, \mathrm{S3}, \mathrm{S4}$, S5 and S6, respectively. The meteorological data of the study site during measurement period have been presented in Table 1.

A dichotomous high volume sampler (Envirotech make - APM460), especially designed to filter coarser particles (larger than $10 \mathrm{~m}$ size) from air stream on $0.5 \mathrm{~m}$ pore size whatman GF/A filter paper, was used for monitoring of Suspended Paticulate Matter (SPM). For gaseous pollutants, an attachment device (make APM 411) with the high volume sampler was used to bubble air in glass impingers filled with absorbing solutions for monitoring of different gaseous pollutants like $\mathrm{SO}_{2}, \mathrm{NO}_{2}$ and $\mathrm{O}_{3}$. During air monitoring, air stream was drawn in the impingers on the roadside from the respirable zone i.e. a height of 1.5 meter above the ground. The gaseous samples were collected by bubbling air in glass impingers filled with $25 \mathrm{ml}$ of different absorbing solutions for different air pollutants i.e. potassium tetra chloro mercurate (TCM) for $\mathrm{SO}_{2}$, sodium hydroxide - sodium arsenite solution for $\mathrm{NO}_{2}$ and potassium iodide solution for $\mathrm{O}_{3}$, at the flow rate of $1.5 \mathrm{~L} / \mathrm{min}$. The samples were brought to the laboratory and analysed within reasonable time, following the standard methods i.e. West and Gaeke (1956) method for $\mathrm{SO}_{2}$, Jacobs and Hochheiser (1958) for $\mathrm{NO}_{2}$ and Byers and Saltzman (1958) for $\mathrm{O}_{3}$.

Air quality index was calculated, following the method of Verma et al. (2003) and on the basis of AQI, quality of ambient air in different localities was adjudged. Firstly, air quality rating of each parameter used for monitoring is calculated separately by the formula as under:

$$
q=100 \times V / V_{s}
$$

where $q$ stands for quality rating, $V$ stands for observed value of the parameter and $V_{s}$ for standard value recommended for that parameter.

If total ' $n$ ' no of parameters were considered for air monitoring, geometric mean of these ' $n$ ' number of quality ratings is calculated in the following way:

$$
\begin{gathered}
(\log a+\log b+\log c+\cdots+\log x) \\
g=\text { anti- } \log n
\end{gathered}
$$

where $g=$ geometric mean, $a, b, c, d, x=$ different values of quality rating, $n=$ numbers of values of quality rating, $\log =$ logarithm.

A relationship between the concentration of different pollutants and traffic density was calculated statistically with the help of coefficient of correlation (Gomez and Gomez, 1984).

\section{Results and Discussion}

The ambient levels of gaseous and particulate pollutants in different localities of trans-Gomti, 
central and southern regions of Lucknow city in different seasons have been reflected in Tables 2-4. Air monitoring data indicate a wide variation in the levels of gaseous and particulate pollutants in different localities of trans-Gomti area of the city in different seasons. Among the 12 road transactions where the air monitoring was undertaken, the air was contaminated maximum with both gaseous and particulate pollutants at site T12, while at site $\mathrm{T} 1$, the air was least polluted. At other sites, the pollutant levels varied between these two extremes, depending upon the vehicular traffic density, type of vehicles and the location.

It was observed that during winter and summer seasons, SPM level was higher than the permissible limit of $200 \mu \mathrm{g} / \mathrm{m}^{3}$ at all the sites except at site T1 and ranged between 80.28 to 995.30 $\mu \mathrm{g} / \mathrm{m}^{3}$ (Tables 2 and 3). The highest SPM level i.e. $995 \mu \mathrm{g} / \mathrm{m}^{3}$ was recorded during winter season at the site T12 with the maximum traffic density (6723 vehicles/h). However, during the rainy season, the SPM level was reduced significantly at all the selected sites of trans-Gomti region (Table 4). The ambient range of SPM load during this season was from $60.09 \mu \mathrm{g} / \mathrm{m}^{3}$ at site $\mathrm{T} 1$ to $641.22 \mu \mathrm{g} / \mathrm{m}^{3}$ at site T12. Except at 4 sites T1, T2, T4 and T8, where the SPM level was found below the permissible limit of $200 \mu \mathrm{g} /$ $\mathrm{m}^{3}$ (60.09, 189.87, 198.34 and $183.54 \mu \mathrm{g} / \mathrm{m}^{3}$, respectively), it was alarmingly higher at other sites than the permissible limit fixed by CPCB.

As far as the atmospheric concentration of gaseous primary pollutants was concerned, $\mathrm{SO}_{2}$ and $\mathrm{NO}_{2}$ levels were also maximum i.e. 41.92 and $38.24 \mu \mathrm{g} / \mathrm{m}^{3}$, respectively, at site T12 during the winter season, while $\mathrm{SO}_{2}$ was not detected and $\mathrm{NO}_{2}$ was measured only $3.20 \mathrm{\mu g} / \mathrm{m}^{3}$ at site $\mathrm{T} 1$ during the rainy season (Tables 2 and 4). It was interesting to note that at no site, the level of $\mathrm{SO}_{2}$ or $\mathrm{NO}_{2}$ was higher than the permissible limit of $60 \mu \mathrm{g} / \mathrm{m}^{3}$ fixed by the CPCB for residential-cum-commercial area. However, $\mathrm{O}_{3}$, which is a secondary pollutant, did not show any specific seasonal pattern in its concentration, but its concentration was generally higher in the summer season. The range of $\mathrm{O}_{3}$ concentrations was between $3.87 \mu \mathrm{g} / \mathrm{m}^{3}$ (at site T2) and $28.59 \mu \mathrm{g} / \mathrm{m}^{3}$ at site T8 during summer season (Table 3 ). Thus, it appears that the levels of gaseous pollutants were not alarming at any site in the trans-Gomti area even in winter season, when the concentrations of these pollutants were maximum.

In central region of Lucknow city, the maximum air contamination, with both particulate and gaseous pollutants in all the seasons, was at the site $\mathrm{C} 9$, while minimum contamination was noted in the premises of site C1 (NBRI). At other sites, the pollution levels varied between these two extremes, depending upon the traffic volume and type of vehicles. It was observed that in all the seasons, the SPM level was higher than the threshold limit at all the sites except site C1 (during all the seasons) and site C2 (during rainy season only). The SPM level in central region of Lucknow city ranged between $105-1005 \mu \mathrm{g} / \mathrm{m}^{3}$ (Tables 2 and 4). The highest SPM level $\left(1005.63 \mu \mathrm{g} / \mathrm{m}^{3}\right.$, during winter season) was recorded at site C9 with a traffic load of 7164 vehicle/h (5669 and 1495 vehicles/h for petrol and diesel vehicles, respectively) (Table 2), whereas lowest SPM level (105.48 $\mu \mathrm{g} / \mathrm{m}^{3}$, during rainy season) was recorded at the site C1 away from the main road (Table 4).

As far as atmospheric level of primary gaseous pollutants was concerned, $\mathrm{SO}_{2}$ and $\mathrm{NO}_{2}$ levels were recorded maximum at site $\mathrm{C} 9(80.52 \mu \mathrm{g} /$ $\left.\mathrm{m}^{3}\right)$ and site C10 $\left(35.87 \mu \mathrm{g} / \mathrm{m}^{3}\right)$, respectively, during winter season (Table 2) and minimum concentrations in the air-shed of central region were measured at site $\mathrm{C} 1$ (4.96 for $\mathrm{SO}_{2}$ and $8.26 \mu \mathrm{g} / \mathrm{m}^{3}$ for $\mathrm{NO}_{2}$ ) during the rainy season (Table 4). The range of $\mathrm{O}_{3}$ concentration in the ambient air of central region was between 2.05 to $26.58 \mu \mathrm{g} / \mathrm{m}^{3}$ with a maximum value at site C10 during the winter season and a minimum value at site C3 during the rainy season (Tables 2 and 4).

Tables 2-4 also reflect the ambient air quality in southern region of Lucknow city. Site S6, which is a commercial-cum residential area 
Table 2 Vehicular traffic density and pollution level in trans-Gomti (T1-T12), central (C1-C10) and southern (S1-S6) regions of Lucknow city in winter season.

\begin{tabular}{|c|c|c|c|c|c|c|c|}
\hline \multirow[t]{2}{*}{ Sites } & \multicolumn{3}{|c|}{ Traffic density (vehicles/hour) $^{a}$} & \multirow{2}{*}{$\frac{\mathrm{SO}_{2}}{\left(\mu \mathrm{g} / \mathrm{m}^{3}\right)}$} & \multirow{2}{*}{$\frac{\mathrm{NO}_{2}}{\left(\mu \mathrm{g} / \mathrm{m}^{3}\right)}$} & \multirow{2}{*}{$\frac{0_{3}}{\left(\mu \mathrm{g} / \mathrm{m}^{3}\right)}$} & \multirow{2}{*}{$\frac{S P M}{\left(\mu g / m^{3}\right)}$} \\
\hline & Diesel & Petrol & Total & & & & \\
\hline $\mathrm{T} 1$ & $42 \pm 6$ & $10 \pm 1$ & $52 \pm 7$ & $\mathrm{Nd}^{\mathrm{b}}$ & 4.29 & 20.00 & 150.00 \\
\hline $\mathrm{T} 2$ & $1639 \pm 64$ & $160 \pm 31$ & $1799 \pm 95$ & 26.50 & 14.03 & 4.39 & 444.40 \\
\hline T3 & $1437 \pm 59$ & $390 \pm 31$ & $1827 \pm 90$ & 26.32 & 25.08 & 4.87 & 438.80 \\
\hline $\mathrm{T} 4$ & $656 \pm 44$ & $97 \pm 11$ & $753 \pm 55$ & 24.58 & 16.66 & 9.79 & 287.03 \\
\hline T5 & $2657 \pm 60$ & $321 \pm 30$ & $2978 \pm 90$ & 34.52 & 16.57 & 4.87 & 458.00 \\
\hline T6 & $546 \pm 31$ & $177 \pm 19$ & $723 \pm 50$ & 26.51 & 18.50 & 22.93 & 495.37 \\
\hline $\mathrm{T} 7$ & $497 \pm 33$ & $321 \pm 37$ & $818 \pm 70$ & 20.00 & 26.73 & 14.14 & 671.29 \\
\hline T8 & $2289 \pm 72$ & $363 \pm 22$ & $2652 \pm 94$ & 38.48 & 21.66 & 27.56 & 427.70 \\
\hline T9 & $1730 \pm 62$ & $166 \pm 27$ & $1896 \pm 89$ & 26.39 & 23.50 & 18.78 & 643.50 \\
\hline $\mathrm{T} 10$ & $917 \pm 50$ & $440 \pm 33$ & $1357 \pm 83$ & 34.42 & 29.38 & 20.75 & 430.54 \\
\hline $\mathrm{T} 11$ & $1369 \pm 63$ & $703 \pm 46$ & $2072 \pm 109$ & 35.46 & 26.13 & 23.68 & 550.92 \\
\hline $\mathrm{T} 12$ & $4552 \pm 190$ & $2171 \pm 89$ & $6723 \pm 279$ & 41.92 & 38.24 & 13.90 & 995.30 \\
\hline C1 & $N A^{c}$ & $N A^{c}$ & $N A^{c}$ & 8.26 & 12.05 & 15.20 & 189.25 \\
\hline $\mathrm{C} 2$ & $488 \pm 18$ & $34 \pm 7$ & $522 \pm 25$ & 12.38 & 11.64 & 11.23 & 312.52 \\
\hline C3 & $1657 \pm 41$ & $24 \pm 6$ & $1861 \pm 47$ & 41.40 & 11.37 & 5.61 & 424.56 \\
\hline C4 & $734 \pm 29$ & $304 \pm 18$ & $1041 \pm 47$ & 28.29 & 19.40 & 6.83 & 452.10 \\
\hline C5 & $1005 \pm 36$ & $504 \pm 38$ & $1509 \pm 74$ & 52.02 & 18.40 & 11.14 & 602.31 \\
\hline $\mathrm{C} 6$ & $759 \pm 32$ & $990 \pm 40$ & $1749 \pm 72$ & 47.08 & 33.37 & 16.95 & 958.55 \\
\hline $\mathrm{C7}$ & $4242 \pm 79$ & $677 \pm 30$ & $4919 \pm 109$ & 70.5 & 13.58 & 23.41 & 896.38 \\
\hline C8 & $3968 \pm 96$ & $812 \pm 36$ & $4780 \pm 132$ & 68.26 & 35.34 & 20.02 & 724.49 \\
\hline C9 & $5669 \pm 126$ & $1495 \pm 47$ & $7164 \pm 173$ & 80.52 & 35.87 & 18.26 & 1005.63 \\
\hline $\mathrm{C} 10$ & $7698 \pm 124$ & $1680 \pm 69$ & $9378 \pm 193$ & 76.85 & 41.09 & 26.58 & 912.50 \\
\hline S1 & $357 \pm 16$ & $34 \pm 3$ & $391 \pm 19$ & 18.72 & 16.55 & 8.26 & 160.00 \\
\hline S2 & $278 \pm 19$ & $42 \pm 5$ & $320 \pm 24$ & 20.86 & 18.29 & 5.91 & 168.62 \\
\hline S3 & $875 \pm 22$ & $61 \pm 5$ & $936 \pm 27$ & 22.88 & 21.95 & 2.00 & 224.20 \\
\hline S4 & $1345 \pm 54$ & $189 \pm 16$ & $1534 \pm 70$ & 30.24 & 22.51 & 16.56 & 380.64 \\
\hline S5 & $1569 \pm 63$ & $219 \pm 18$ & $1788 \pm 81$ & 38.51 & 22.90 & 22.02 & 498.53 \\
\hline S6 & $1807 \pm 60$ & $341 \pm 23$ & $2148 \pm 83$ & 41.10 & 26.58 & 17.02 & 589.65 \\
\hline
\end{tabular}

avalues are mean \pm S.D. $(n=5)$.

${ }^{\mathrm{b}} \mathrm{Nd}=$ Not detected .

${ }^{\mathrm{N}} \mathrm{N}=$ = Not Available. 
Table 3 Vehicular traffic density and pollution level in trans-Gomti (T1-T12), central (C1-C10) and southern (S1-S6) regions of Lucknow city in summer season.

\begin{tabular}{|c|c|c|c|c|c|c|c|}
\hline \multirow[t]{2}{*}{ Sites } & \multicolumn{3}{|c|}{ Traffic density (vehicles/hour) ${ }^{a}$} & \multirow{2}{*}{$\frac{\mathrm{SO}_{2}}{\left(\mu \mathrm{g} / \mathrm{m}^{3}\right)}$} & \multirow{2}{*}{$\frac{\mathrm{NO}_{2}}{\left(\mu \mathrm{g} / \mathrm{m}^{3}\right)}$} & \multirow{2}{*}{$\frac{0_{3}}{\left(\mu \mathrm{g} / \mathrm{m}^{3}\right)}$} & \multirow{2}{*}{$\frac{\text { SPM }}{\left(\mu \mathrm{g} / \mathrm{m}^{3}\right)}$} \\
\hline & Diesel & Petrol & Total & & & & \\
\hline $\mathrm{T} 1$ & $50 \pm 6$ & $3 \pm 1$ & $53 \pm 7$ & $\mathrm{Nd}^{b}$ & 09.58 & 28.54 & 80.28 \\
\hline $\mathrm{T} 2$ & $1758 \pm 52$ & $195 \pm 16$ & $1953 \pm 68$ & 25.12 & 15.28 & 03.87 & 348.52 \\
\hline T3 & $1289 \pm 54$ & $451 \pm 39$ & $1640 \pm 93$ & 25.28 & 20.54 & 12.85 & 587.98 \\
\hline $\mathrm{T} 4$ & $714 \pm 39$ & $102 \pm 9$ & $816 \pm 48$ & 23.58 & 12.35 & 10.28 & 349.75 \\
\hline T5 & $2280 \pm 78$ & $286 \pm 20$ & $2566 \pm 98$ & 35.85 & 15.08 & 14.52 & 648.34 \\
\hline T6 & $550 \pm 22$ & $165 \pm 18$ & $715 \pm 40$ & 27.54 & 15.82 & 19.85 & 359.18 \\
\hline $\mathrm{T7}$ & $512 \pm 40$ & $295 \pm 20$ & $807 \pm 60$ & 21.85 & 37.45 & 11.37 & 784.46 \\
\hline T8 & $2560 \pm 81$ & $412 \pm 34$ & $2972 \pm 115$ & 40.00 & 20.23 & 28.59 & 312.12 \\
\hline T9 & $1697 \pm 68$ & $257 \pm 21$ & $1954 \pm 89$ & 22.86 & 22.52 & 22.78 & 487.29 \\
\hline $\mathrm{T} 10$ & $892 \pm 42$ & $485 \pm 19$ & $1377 \pm 61$ & 40.43 & 30.25 & 15.83 & 512.45 \\
\hline $\mathrm{T} 11$ & $1562 \pm 60$ & $785 \pm 29$ & $2347 \pm 89$ & 30.28 & 25.84 & 20.41 & 780.27 \\
\hline $\mathrm{T} 12$ & $4268 \pm 89$ & $1529 \pm 55$ & $5797 \pm 144$ & 39.29 & 29.22 & 18.27 & 957.59 \\
\hline $\mathrm{C} 1$ & $N A^{c}$ & $N A^{c}$ & $N A^{c}$ & 8.12 & 10.03 & 16.00 & 170.49 \\
\hline $\mathrm{C} 2$ & $512 \pm 21$ & $84 \pm 6$ & $596 \pm 27$ & 10.12 & 10.52 & 16.32 & 360.25 \\
\hline $\mathrm{C} 3$ & $1509 \pm 50$ & $58 \pm 6$ & $1567 \pm 56$ & 36.58 & 10.56 & 4.56 & 386.49 \\
\hline $\mathrm{C} 4$ & $852 \pm 30$ & $385 \pm 15$ & $1237 \pm 45$ & 20.15 & 15.23 & 6.52 & 300.28 \\
\hline C5 & $1112 \pm 30$ & $548 \pm 35$ & $1660 \pm 65$ & 47.25 & 13.21 & 6.42 & 628.08 \\
\hline $\mathrm{C} 6$ & $813 \pm 26$ & $824 \pm 47$ & $1637 \pm 73$ & 41.32 & 32.22 & 12.65 & 900.58 \\
\hline $\mathrm{C} 7$ & $4085 \pm 63$ & $598 \pm 32$ & $4683 \pm 95$ & 64.34 & 22.85 & 12.38 & 798.64 \\
\hline $\mathrm{C} 8$ & $3825 \pm 89$ & $1005 \pm 31$ & $4830 \pm 120$ & 65.08 & 30.98 & 21.09 & 618.53 \\
\hline $\mathrm{Cg}$ & $5284 \pm 102$ & $1500 \pm 42$ & $6784 \pm 144$ & 78.92 & 32.85 & 17.96 & 995.85 \\
\hline $\mathrm{C} 10$ & $7542 \pm 118$ & $1380 \pm 70$ & $8922 \pm 188$ & 74.23 & 39.85 & 25.25 & 924.16 \\
\hline S1 & $321 \pm 9$ & $29 \pm 2$ & $350 \pm 11$ & 19.51 & 15.29 & 4.92 & 149.34 \\
\hline S2 & $286 \pm 19$ & $38 \pm 3$ & $324 \pm 22$ & 20.42 & 17.31 & 6.85 & 159.65 \\
\hline S3 & $816 \pm 20$ & $54 \pm 4$ & $870 \pm 24$ & 21.98 & 19.86 & 5.06 & 222.75 \\
\hline S4 & $1300 \pm 58$ & $157 \pm 12$ & $1457 \pm 70$ & 28.96 & 21.89 & 11.96 & 359.48 \\
\hline S5 & $1492 \pm 60$ & $194 \pm 16$ & $1686 \pm 76$ & 30.09 & 21.48 & 28.44 & 442.98 \\
\hline S6 & $1650 \pm 56$ & $312 \pm 21$ & $1962 \pm 77$ & 39.27 & 24.98 & 15.82 & 548.52 \\
\hline
\end{tabular}

aValues are mean \pm S.D. $(n=5)$.

${ }^{\mathrm{D}} \mathrm{Nd}=$ Not detected.

cNA $=$ Not Available . 
Table 4 Vehicular traffic density and pollution level in trans-Gomti (T1-T12), central (C1-C10) and southern (S1-S6) regions of Lucknow city in rainy season.

\begin{tabular}{|c|c|c|c|c|c|c|c|}
\hline \multirow[t]{2}{*}{ Sites } & \multicolumn{3}{|c|}{ Traffic density (vehicles/hour)a } & \multirow{2}{*}{$\frac{\mathrm{SO}_{2}}{\left(\mu \mathrm{g} / \mathrm{m}^{3}\right)}$} & \multirow{2}{*}{$\frac{\mathrm{NO}_{2}}{\left(\mu \mathrm{g} / \mathrm{m}^{3}\right)}$} & \multirow{2}{*}{$\begin{array}{c}0_{3} \\
\left(\mu \mathrm{g} / \mathrm{m}^{3}\right)\end{array}$} & \multirow{2}{*}{$\frac{\text { SPM }}{\left(\mu \mathrm{g} / \mathrm{m}^{3}\right)}$} \\
\hline & Diesel & Petrol & Total & & & & \\
\hline $\mathrm{T} 1$ & $23 \pm 3$ & $2 \pm 1$ & $25 \pm 4$ & $\mathrm{Nd}^{b}$ & 3.20 & 15.86 & 60.09 \\
\hline T2 & $1265 \pm 21$ & $151 \pm 12$ & $1416 \pm 33$ & 18.96 & 9.64 & 5.23 & 189.87 \\
\hline T3 & $1024 \pm 68$ & $320 \pm 16$ & $1344 \pm 84$ & 12.36 & 11.80 & 6.59 & 312.12 \\
\hline $\mathrm{T} 4$ & $497 \pm 11$ & $100 \pm 8$ & $597 \pm 19$ & 15.78 & 8.26 & 5.94 & 198.34 \\
\hline T5 & $2058 \pm 71$ & $219 \pm 12$ & $2277 \pm 83$ & 28.95 & 9.22 & 8.26 & 416.38 \\
\hline T6 & $428 \pm 12$ & $150 \pm 15$ & $578 \pm 27$ & 16.85 & 9.54 & 11.24 & 248.84 \\
\hline $\mathrm{T} 7$ & $318 \pm 11$ & $284 \pm 19$ & $602 \pm 30$ & 12.58 & 21.05 & 6.82 & 518.95 \\
\hline T8 & $1892 \pm 68$ & $320 \pm 16$ & $2212 \pm 84$ & 28.54 & 13.08 & 14.29 & 183.54 \\
\hline T9 & $1492 \pm 33$ & $148 \pm 14$ & $1640 \pm 47$ & 19.52 & 15.27 & 13.50 & 286.20 \\
\hline $\mathrm{T} 10$ & $802 \pm 27$ & $321 \pm 18$ & $1123 \pm 45$ & 30.00 & 30.25 & 11.00 & 214.85 \\
\hline $\mathrm{T} 11$ & $1257 \pm 40$ & $615 \pm 26$ & $1872 \pm 66$ & 21.53 & 19.82 & 9.18 & 487.28 \\
\hline $\mathrm{T} 12$ & $4025 \pm 84$ & $1582 \pm 43$ & $5607 \pm 127$ & 35.42 & 27.46 & 12.05 & 641.22 \\
\hline C1 & $N A^{c}$ & $N A^{c}$ & $N A^{c}$ & 4.96 & 8.26 & 10.85 & 105.48 \\
\hline $\mathrm{C} 2$ & $312 \pm 17$ & $84 \pm 7$ & $396 \pm 24$ & 6.39 & 5.28 & 15.05 & 180.25 \\
\hline C3 & $1284 \pm 43$ & $81 \pm 5$ & $1365 \pm 48$ & 25.54 & 10.56 & 2.05 & 278.52 \\
\hline C4 & $575 \pm 24$ & $324 \pm 16$ & $899 \pm 40$ & 21.08 & 18.26 & 2.15 & 198.71 \\
\hline C5 & $868 \pm 23$ & $248 \pm 29$ & $1116 \pm 52$ & 34.71 & 11.28 & 2.59 & 451.00 \\
\hline C6 & $619 \pm 39$ & $487 \pm 43$ & $1106 \pm 82$ & 26.05 & 20.20 & 10.24 & 484.42 \\
\hline $\mathrm{C7}$ & $3452 \pm 68$ & $586 \pm 29$ & $4038 \pm 97$ & 36.52 & 20.64 & 10.07 & 512.44 \\
\hline C8 & $2102 \pm 73$ & $516 \pm 22$ & $2618 \pm 95$ & 48.38 & 24.86 & 15.28 & 357.61 \\
\hline C9 & $3852 \pm 84$ & $689 \pm 39$ & $4541 \pm 123$ & 60.53 & 29.40 & 20.02 & 700.18 \\
\hline $\mathrm{C} 10$ & $7219 \pm 101$ & $1325 \pm 63$ & $8544 \pm 164$ & 62.53 & 34.18 & 18.12 & 681.28 \\
\hline S1 & $314 \pm 8$ & $21 \pm 3$ & $335 \pm 11$ & 14.56 & 11.82 & 3.58 & 132.56 \\
\hline S2 & $295 \pm 19$ & $30 \pm 3$ & $325 \pm 22$ & 19.42 & 14.71 & 4.68 & 140.26 \\
\hline S3 & $794 \pm 21$ & $51 \pm 5$ & $845 \pm 26$ & 18.25 & 12.96 & 4.84 & 200.51 \\
\hline S4 & $1262 \pm 54$ & $140 \pm 12$ & $1402 \pm 66$ & 20.51 & 16.52 & 8.52 & 300.52 \\
\hline S5 & $1485 \pm 62$ & $148 \pm 14$ & $1633 \pm 76$ & 29.998 & 18.24 & 21.86 & 214.86 \\
\hline S6 & $1621 \pm 52$ & $284 \pm 20$ & $1905 \pm 72$ & 22.08 & 20.08 & 16.38 & 458.62 \\
\hline
\end{tabular}

avalues are maen \pm S.D. $(n=5)$.

${ }^{\mathrm{D}} \mathrm{Nd}=$ Not detected.

cNA $=$ Not Available. 
of the southern region, was found to be maximally contaminated with both particulate and gaseous pollutants, while site $\mathrm{S} 1$, which is a purely residential open spaced colony, was least polluted with these pollutants. During all the seasons, it was observed that particulate pollution level (SPM level) at sites S3, S4, S5 and $\mathrm{S} 6$ was higher than the permissible limit, whereas, at rest of the sites, i.e. S1 and S2, the SPM level was below the threshold limit. The range of SPM levels in the southern region of Lucknow city was between 132.56 and 589.65 $\mu \mathrm{g} / \mathrm{m}^{3}$ (Tables 2 and 4 ). The highest SPM level was recorded during the winter season at site S6 $\left(589.65 \mu \mathrm{g} / \mathrm{m}^{3}\right)$ with a traffic density of 2148 vehicles/h (1807 for petrol and 341 for diesel) (Table 2) and the lowest SPM level was noted during the rainy season at site $\mathrm{S} 1\left(132.56 \mu \mathrm{g} / \mathrm{m}^{3}\right)$ with a traffic load of 335 vehicles/h (314 for petrol and 21 for diesel) (Table 4).

Similarly, $\mathrm{SO}_{2}$ and $\mathrm{NO}_{2}$ levels were also recorded maximum i.e. 41.10 and $26.58 \mu \mathrm{g} /$ $\mathrm{m}^{3}$, respectively, at site $\mathrm{S} 6$ during the winter season (Table 4) and minimum (14.56 and $11.82 \mu \mathrm{g} / \mathrm{m}^{3}$, respectively) in the ambient air at site $\mathrm{S} 1$ during the rainy season (Table 4). As far as the concentration of $\mathrm{O}_{3}$ is concerned, no specific trend was observed as in other regions with respect to vehicular traffic volume. The range of $\mathrm{O}_{3}$ concentration in the ambient air of southern region was between a lowest of 2.0 $\mu \mathrm{g} / \mathrm{m}^{3}$ at site S3 during the winter season and a highest of $28.44 \mu \mathrm{g} / \mathrm{m}^{3}$ at site S5 during the summer season (Tables 2 and 3 ).

Levels of $\mathrm{SO}_{2}, \mathrm{NO}_{2}, \mathrm{O}_{3}$ and SPM at different sites selected in three different regions of Lucknow city clearly indicated a pattern of seasonal variation. It was observed that the concentrations of these pollutants were at their peak during the winter season and minimum during the rainy season at all the road intersections. At the most polluted site of trans-Gomti region i.e. site $\mathrm{T} 12$, the concentration of $\mathrm{SO}_{2}$ was found to be 41.92 in winter season, 39.29 in summer season and $35.42 \mu \mathrm{g} / \mathrm{m}^{3}$ in rainy season, the $\mathrm{NO}_{2}$ concentrations was 38.24 in winter season, 29.22 in summer season and $27.46 \mu \mathrm{g} / \mathrm{m}^{3}$ in rainy season and SPM concentration was $995.30 \mu \mathrm{g} / \mathrm{m}^{3}$ during winter season, $957.59 \mu \mathrm{g} / \mathrm{m}^{3}$ during summer season and $641.22 \mu \mathrm{g} / \mathrm{m}^{3}$ during rainy season. However, $\mathrm{O}_{3}$ concentration was 18.27 in summer season, 13.90 in winter season, and $12.05 \mu \mathrm{g} / \mathrm{m}^{3}$ in rainy season (Table $2-4$ ).

A decline in the concentrations of individual pollutants from winter to rainy seasons has been noted at different selected sites in 3 regions of Lucknow city. It was noted that in trans-Gomti region, maximum decrease in $\mathrm{SO}_{2}$ level was at site T3 (53\%); in $\mathrm{NO}_{2}$ at site T3 $(53 \%)$ and in SPM at site T8 (57\%), whereas, minimum decrease in $\mathrm{SO}_{2}, \mathrm{NO}_{2}$ and SPM pollutants was of the order of $12.8 \%$ (at site T10), $2.1 \%$ (at site T10) and 9\% (at site T5), respectively. In central region, the significant decrease in these pollutants observed was $48.4 \%$ (at site C2) for $\mathrm{SO}_{2}, 54.6 \%$ (at site C2) for $\mathrm{NO}_{2}$ and $50.6 \%$ (at site C8) for SPM, whereas a moderate decrease was noted in the order of $18.6 \%$ (for $\mathrm{SO}_{2}$ ), 5.8\% (for $\mathrm{NO}_{2}$ ) and $25.1 \%$ (for SPM) at sites C10, C4, C5, respectively. Likewise, in the southern region, a remarkable decrease in $\mathrm{SO}_{2}, \mathrm{NO}_{2}$ and SPM levels was noted at site $\mathrm{S} 6$ $(46.3 \%)$, site S3 (4.10\%) and site S5 (56.6\%), respectively and a moderate decline in $\mathrm{SO}_{2}$, $\mathrm{NO}_{2}$ and SPM was observed at site S2 $(7.0 \%)$, site S2 $(19.5 \%)$ and site S3 (10.5\%), respectively. No specific trend in decline of ozone concentration was observed with respect to different seasons. In this study, the different localities of three selected regions of Lucknow city were categorized on the basis of AQI as presented in Tables 5-7. Apart from it, season-wise AQI was also calculated to categorize the different sites in three regions of the Lucknow city. In transGomti region, a maximum index value (68.42) was observed for site T12 during winter season (Table 5), whereas minimum index value (2.77) was noted for site $\mathrm{T} 1$ during rainy season (Table 7). On the basis of AQI, the quality of ambient air in different localities was adjudged and it was found that during winter season, the site T1 was of very clear category; sites T2, T3, T4, T5, T6 
and T7 came under fairly clean category, while, sites T8, T9, T10, T11 and T12 were moderately polluted (Table 5). During summer season, the site T1 was very clean, sites T2, T3, T4, T5, T6, and T9 were under fairly clean category, and under moderately polluted category, were placed sites T7, T8, T10, T11 and T12 (Table 6). In the same way, during rainy season, again site $\mathrm{T} 1$ was found to be very clean; sites T2, T3 and T4 were under clean category; sites T5, T6, T7, T8, T9, T10 and T11 were put under fairly clean category and only one site i.e. T12, fell under moderately polluted category (Table 7 ). In order to find out the relationship between $A Q I$ and traffic density at different sites of trans-Gomti region, a coefficient of correlation was calculated between these two variables and a value of $R^{2}=0.58(p>0.05)$ was found for winter season, $R^{2}=0.59(p>0.05)$ for summer season and $R^{2}=0.76(p>0.05)$ for rainy season.

Seasonal AQI of central region of Lucknow city was also calculated and data were presented in Tables 4-6. It was observed that the site C10 showed the maximum index value (93.00) during the winter season (Table 5), whereas, the minimum index value (14.63) was observed at site $\mathrm{C} 1$ during the rainy season (Table 6). On the basis of AQI, air quality of different localities was assessed, which reflected that during winter season, site $\mathrm{C} 1$ was under clean category; sites C2, C3, C4 and C7 were under fairly clean category; sites C5 and C6 were moderately polluted; whereas, sites $\mathrm{C} 8, \mathrm{C} 9$ and $\mathrm{C} 10$ were polluted ones (Table 6). In the summer season, site S1 was again under clean category; sites C2 C3, C4 and C5 were fairly clean; sites C6, $\mathrm{C} 7$ and $\mathrm{C} 8$ were under moderately polluted category; whereas, C9 and C10 were placed in the polluted category (Table 6). However, during the rainy season, the situation has changed drastically. The sites C1, C2, C3 and C4 fell under clean category, sites $\mathrm{C} 5, \mathrm{C} 6$ and $\mathrm{C} 7$ were found to be fairly clean and sites C8, C9 and C10 were under moderately polluted category. Interestingly, during rainy season, no site was found to be under polluted category in contrast to winter and summer seasons (Table 7).
In central region also, a coefficient of correlation was calculated between AQI and the traffic density, which gave a relationship of $R^{2}=0.85$ $(p>0.01)$ in winter season, $R^{2}=0.92(p>0.01)$ in summer season and $R^{2}=0.88(p>0.01)$ in rainy season.

Likewise, on the basis of the concentrations of different pollutants in the air-shed, air quality index (AQI) of southern region was also calculated and different sites of this region were also placed into different categories (Tables 5-7). The maximum value of $A Q I$ was noted for site S6 (57.20) during the winter season (Table 5), while the minimum value (16.81) was observed for site $\mathrm{S} 1$ during the rainy season (Table 7 ). At other sites, the index values varied between these two extremes. During the winter season, sites S2 and S3 were under clean category; sites S1 and S4 were under fairly clean category; whereas, sites S5 and S6 were found to be moderately polluted (Table 5). Likewise, during the summer season, sites S1 and S2 were under clean category; sites S3 and S4 were under fairly clean category; whereas, sites S5 and S6 were kept under moderately polluted category (Table 6). However, during the rainy season, sites S1, S2 and S3 were placed under clean category and sites S4, S5 and S6 were under fairly clean category (Table 7). There was no site placed under moderately polluted category in the rainy season. The correlation between the air quality index and vehicular traffic volume in southern region was calculated as $R^{2}=0.93(p>0.01)$ in winter season, $R^{2}=0.95(p>0.01)$ in summer season and $R^{2}=0.96(p>0.01)$ in rainy season.

On average basis, in the trans-Gomti region, the kukrail forest picnic spot $\left(\mathrm{SO}_{2}\right.$, Not detected; $\mathrm{NO}_{2}, 5.69 ; \mathrm{O}_{3}, 23.47$ and SPM, $96.79 \mu \mathrm{g} \mathrm{m}^{-3}$ ) and IT crossing $\left(\mathrm{SO}_{2}, 38.88 ; \mathrm{NO}_{2}, 31.64 ; \mathrm{O}_{3}\right.$, 14.74 and SPM, $864.70 \mu \mathrm{g} \mathrm{m}^{-3}$ ) were found to be the minimally and maximally polluted; in the central region, Pariwartan sqare $\left(\mathrm{SO}_{2}, 71.20\right.$; $\mathrm{NO}_{2}, 38.37 ; \mathrm{O}_{3}, 23.32$ and SPM, 839.31 $\mu \mathrm{g} \mathrm{m}^{-3}$ ) was highly polluted, while the $\mathrm{NBRI}\left(\mathrm{SO}_{2}, 7.11\right.$; $\mathrm{NO}_{2}, 10.11 ; \mathrm{O}_{3}, 14.02$ and SPM, $155.07 \mu \mathrm{g} \mathrm{m}^{-3}$ ) 
Table 5 Site-wise categorization of air quality in trans-Gomti (T1-T12), central (C1-C10) and southern (S1-S6) regions of Lucknow city on the basis of Air Quality Index a during the winter season.

\begin{tabular}{|c|c|c|c|c|c|c|}
\hline \multirow{2}{*}{ Sites } & \multicolumn{4}{|c|}{ Quality rating } & \multirow{2}{*}{ Air quality index } & \multirow{2}{*}{ Air quality category } \\
\hline & SPM & $\mathrm{SO}_{2}$ & $\mathrm{NO}_{2}$ & $\mathrm{O}_{3}$ & & \\
\hline $\mathrm{T} 1$ & 75 & $\mathrm{Nd}^{b}$ & 5 & 25 & 9.89 & Very clean \\
\hline $\mathrm{T} 2$ & 222 & 33 & 18 & 5 & 28.52 & Fairly clean \\
\hline T3 & 219 & 33 & 31 & 6 & 33.52 & Fairly clean \\
\hline $\mathrm{T} 4$ & 144 & 31 & 21 & 12 & 32.74 & Fairly clean \\
\hline T5 & 229 & 43 & 21 & 6 & 33.51 & Fairly clean \\
\hline T6 & 248 & 33 & 23 & 29 & 48.46 & Fairly clean \\
\hline $\mathrm{T} 7$ & 336 & 25 & 33 & 18 & 47.35 & Fairly clean \\
\hline T8 & 214 & 48 & 27 & 34 & 55.59 & Moderately polluted \\
\hline T9 & 322 & 33 & 29 & 23 & 51.89 & Moderately polluted \\
\hline $\mathrm{T} 10$ & 215 & 43 & 37 & 26 & 58.26 & Moderately polluted \\
\hline $\mathrm{T} 11$ & 275 & 44 & 33 & 30 & 58.25 & Moderately polluted \\
\hline $\mathrm{T} 12$ & 498 & 52 & 48 & 17 & 68.42 & Moderately polluted \\
\hline $\mathrm{C} 1$ & 95 & 10 & 15 & 19 & 22.99 & Clean \\
\hline $\mathrm{C} 2$ & 156 & 15 & 15 & 14 & 26.51 & Fairly clean \\
\hline $\mathrm{C} 3$ & 212 & 52 & 14 & 7 & 32.35 & Fairly clean \\
\hline $\mathrm{C} 4$ & 226 & 35 & 24 & 9 & 35.86 & Fairly clean \\
\hline $\mathrm{C} 5$ & 301 & 65 & 23 & 14 & 50.04 & Moderately polluted \\
\hline $\mathrm{C} 6$ & 479 & 59 & 42 & 21 & 70.66 & Moderately polluted \\
\hline $\mathrm{C} 7$ & 448 & 88 & 29 & 4 & 47.19 & Fairly clean \\
\hline $\mathrm{C} 8$ & 362 & 85 & 44 & 25 & 76.45 & Polluted \\
\hline $\mathrm{Cg}$ & 503 & 101 & 45 & 23 & 84.82 & Polluted \\
\hline $\mathrm{C} 10$ & 456 & 96 & 51 & 33 & 93.00 & Polluted \\
\hline S1 & 80 & 23 & 21 & 10 & 25.15 & Clean \\
\hline $\mathrm{S} 2$ & 84 & 26 & 23 & 7 & 24.68 & Clean \\
\hline S3 & 112 & 29 & 27 & 3 & 21.66 & Clean \\
\hline S4 & 190 & 38 & 28 & 21 & 45.24 & Fairly clean \\
\hline S5 & 249 & 48 & 29 & 28 & 55.45 & Moderately polluted \\
\hline S6 & 295 & 51 & 33 & 21 & 57.20 & Moderately polluted \\
\hline
\end{tabular}

${ }^{a} \mathrm{AQI} \leq 10$, very clean; $10-25$, clean; $25-50$, fairly clean; $50-75$, moderately polluted; $75-100$, polluted; $100-125$ heavily polluted and $\geq 125$, severely polluted (Mudri, 1999). ${ }^{\mathrm{D}} \mathrm{Nd}=$ Not detected. 
Table 6 Site-wise categorization of air quality in trans-Gomti (T1-T12), central (C1-C10) and southern (S1-S6) regions of Lucknow city on the basis of Air Quality Index a during the summer season.

\begin{tabular}{|c|c|c|c|c|c|c|}
\hline \multirow{2}{*}{ Sites } & \multicolumn{4}{|c|}{ Quality rating } & \multirow{2}{*}{ Air quality index } & \multirow{2}{*}{ Air quality category } \\
\hline & SPM & $\mathrm{SO}_{2}$ & $\mathrm{NO}_{2}$ & $\mathrm{O}_{3}$ & & \\
\hline $\mathrm{T} 1$ & 40 & $\mathrm{Nd}^{b}$ & 12 & 36 & 7.65 & Very clean \\
\hline $\mathrm{T} 2$ & 174 & 31 & 19 & 5 & 26.60 & Fairly clean \\
\hline T3 & 294 & 32 & 26 & 16 & 44.24 & Fairly clean \\
\hline T4 & 175 & 29 & 15 & 13 & 31.79 & Fairly clean \\
\hline T5 & 324 & 45 & 19 & 18 & 47.21 & Fairly clean \\
\hline T6 & 180 & 34 & 19 & 25 & 41.73 & Fairly clean \\
\hline $\mathrm{T} 7$ & 392 & 27 & 47 & 14 & 51.66 & Moderately polluted \\
\hline T8 & 156 & 50 & 25 & 35 & 51.53 & Moderately polluted \\
\hline T9 & 244 & 29 & 28 & 28 & 48.60 & Fairly clean \\
\hline $\mathrm{T} 10$ & 256 & 51 & 38 & 20 & 55.79 & Moderately polluted \\
\hline $\mathrm{T} 11$ & 390 & 38 & 32 & 26 & 59.06 & Moderately polluted \\
\hline $\mathrm{T} 12$ & 479 & 49 & 37 & 23 & 66.55 & Moderately polluted \\
\hline C1 & 85 & 10 & 13 & 20 & 21.58 & Clean \\
\hline $\mathrm{C} 2$ & 180 & 12 & 13 & 20 & 27.96 & Fairly clean \\
\hline C3 & 193 & 46 & 13 & 6 & 28.55 & Fairly clean \\
\hline C4 & 150 & 25 & 19 & 8 & 27.67 & Fairly clean \\
\hline C5 & 314 & 59 & 17 & 8 & 39.59 & Fairly clean \\
\hline $\mathrm{C} 6$ & 450 & 52 & 42 & 16 & 62.51 & Moderately polluted \\
\hline $\mathrm{C7}$ & 399 & 80 & 29 & 15 & 61.38 & Moderately polluted \\
\hline $\mathrm{C} 8$ & 309 & 81 & 39 & 26 & 71.19 & Moderately polluted \\
\hline C9 & 498 & 99 & 41 & 22 & 82.03 & Polluted \\
\hline $\mathrm{C} 10$ & 462 & 93 & 50 & 32 & 90.61 & Polluted \\
\hline S1 & 75 & 24 & 19 & 6 & 21.51 & Clean \\
\hline S2 & 80 & 26 & 22 & 9 & 24.78 & Clean \\
\hline S3 & 111 & 27 & 25 & 6 & 26.32 & Fairly clean \\
\hline S4 & 180 & 36 & 27 & 15 & 40.39 & Fairly clean \\
\hline S5 & 221 & 44 & 27 & 36 & 55.18 & Moderately polluted \\
\hline S6 & 274 & 49 & 31 & 20 & 53.60 & Moderately polluted \\
\hline
\end{tabular}

${ }^{\mathrm{a}} \mathrm{AQI} \leq 10$, very clean; $10-25$, clean; $25-50$, fairly clean; 50-75, moderately polluted; $75-100$, polluted; $100-125$ heavily polluted and $\geq 125$, severely polluted (Mudri, 1999).

${ }^{b} \mathrm{Nd}=$ Not detected. 
Table 7 Site-wise categorization of air quality in trans-Gomti (T1-T12), central (C1-C10) and southern (S1-S6) region of Lucknow city on the basis of Air Quality Index a during the rainy season.

\begin{tabular}{|c|c|c|c|c|c|c|}
\hline \multirow{2}{*}{ Sites } & \multicolumn{4}{|c|}{ Quality rating } & \multirow{2}{*}{ Air quality index } & \multirow{2}{*}{ Air quality category } \\
\hline & SPM & $\mathrm{SO}_{2}$ & $\mathrm{NO}_{2}$ & $\mathrm{O}_{3}$ & & \\
\hline $\mathrm{T} 1$ & 30 & $\mathrm{Nd}^{\mathrm{b}}$ & 4 & 20 & 2.77 & Very clean \\
\hline $\mathrm{T} 2$ & 95 & 24 & 12 & 7 & 20.60 & Clean \\
\hline T3 & 156 & 15 & 15 & 8 & 23.26 & Clean \\
\hline $\mathrm{T} 4$ & 99 & 20 & 10 & 7 & 19.67 & Clean \\
\hline T5 & 208 & 36 & 12 & 10 & 30.77 & Fairly clean \\
\hline T6 & 124 & 21 & 12 & 14 & 25.74 & Fairly clean \\
\hline $\mathrm{T} 7$ & 259 & 16 & 26 & 9 & 30.93 & Fairly clean \\
\hline T8 & 92 & 36 & 16 & 18 & 31.27 & Fairly clean \\
\hline T9 & 143 & 24 & 19 & 17 & 32.56 & Fairly clean \\
\hline T10 & 107 & 51 & 38 & 13 & 40.98 & Fairly clean \\
\hline T11 & 244 & 27 & 25 & 11 & 36.95 & Fairly clean \\
\hline $\mathrm{T} 12$ & 321 & 44 & 34 & 15 & 52.04 & Moderately polluted \\
\hline C1 & 53 & 6 & 10 & 14 & 14.63 & Clean \\
\hline $\mathrm{C} 2$ & 90 & 8 & 7 & 19 & 17.29 & Clean \\
\hline C3 & 139 & 32 & 13 & 3 & 19.69 & Clean \\
\hline C4 & 99 & 26 & 23 & 3 & 20.01 & Clean \\
\hline C5 & 226 & 43 & 14 & 3 & 25.85 & Fairly clean \\
\hline C6 & 242 & 33 & 25 & 13 & 39.96 & Fairly clean \\
\hline $\mathrm{C7}$ & 256 & 46 & 26 & 13 & 44.15 & Fairly clean \\
\hline C8 & 179 & 60 & 31 & 19 & 50.33 & Moderately polluted \\
\hline C9 & 350 & 76 & 37 & 25 & 70.25 & Moderately polluted \\
\hline C10 & 341 & 78 & 43 & 23 & 71.25 & Moderately Polluted \\
\hline S1 & 66 & 18 & 15 & 4 & 16.81 & Clean \\
\hline S2 & 70 & 24 & 18 & 6 & 20.69 & Clean \\
\hline S3 & 100 & 23 & 16 & 6 & 21.76 & Clean \\
\hline S4 & 150 & 26 & 21 & 11 & 30.34 & Fairly clean \\
\hline S5 & 107 & 37 & 23 & 27 & 39.80 & Fairly clean \\
\hline S6 & 229 & 28 & 25 & 20 & 42.47 & Fairly clean \\
\hline
\end{tabular}

${ }^{a} \mathrm{AQI} \leq 10$, very clean; $10-25$, clean; $25-50$, fairly clean; $50-75$, moderately polluted; $75-100$, polluted; $100-125$ heavily polluted and $\geq 125$, severely polluted (Mudri, 1999).

${ }^{\mathrm{b}} \mathrm{Nd}=$ Not detected. 
was least polluted; while in the southern region, Ashiyana colony $\left(\mathrm{SO}_{2}, 17.60 ; \mathrm{NO}_{2}, 14.55 ; \mathrm{O}_{3}\right.$, 5.59 and SPM, $147.30 \mu \mathrm{g} \mathrm{m}^{-3}$ ) and Alambagh $\left(\mathrm{SO}_{2}, 34.15 ; \mathrm{NO}_{2}, 23.80 ; \mathrm{O}_{3}, 16.41\right.$ and $\mathrm{SPM}$, $532.26 \mu \mathrm{g} \mathrm{m}^{-3}$ ) were least and highly polluted, respectively (Figure 1 ).

Lastly, on the basis of AQI, in trans-Gomti region, different sites may be arrested in an order of increasing pollution levels as T1 $<\mathrm{T} 2$ $<\mathrm{T} 3<\mathrm{T} 4<\mathrm{T} 5<\mathrm{T} 6<\mathrm{T} 7<\mathrm{T} 8<\mathrm{T} 9<\mathrm{T} 10$
$<\mathrm{T} 11<\mathrm{T} 12$, in central region in an order of $\mathrm{C} 1<\mathrm{C} 2<\mathrm{C} 3<\mathrm{C} 4<\mathrm{C} 5<\mathrm{C} 6<\mathrm{C} 7<\mathrm{C} 8<$ $\mathrm{C} 9<\mathrm{C} 10$ and in southern region an order of $\mathrm{S} 1<\mathrm{S} 2<\mathrm{S} 3<\mathrm{S} 4<\mathrm{S} 5<\mathrm{S} 6$. This trend corresponded to the traffic density in respective regions. Generally, two steps are required to adopt the strategies for the abatement of air pollution in a particular locality or region. The first step is air monitoring, which enables us to know the actual air quality status of the region

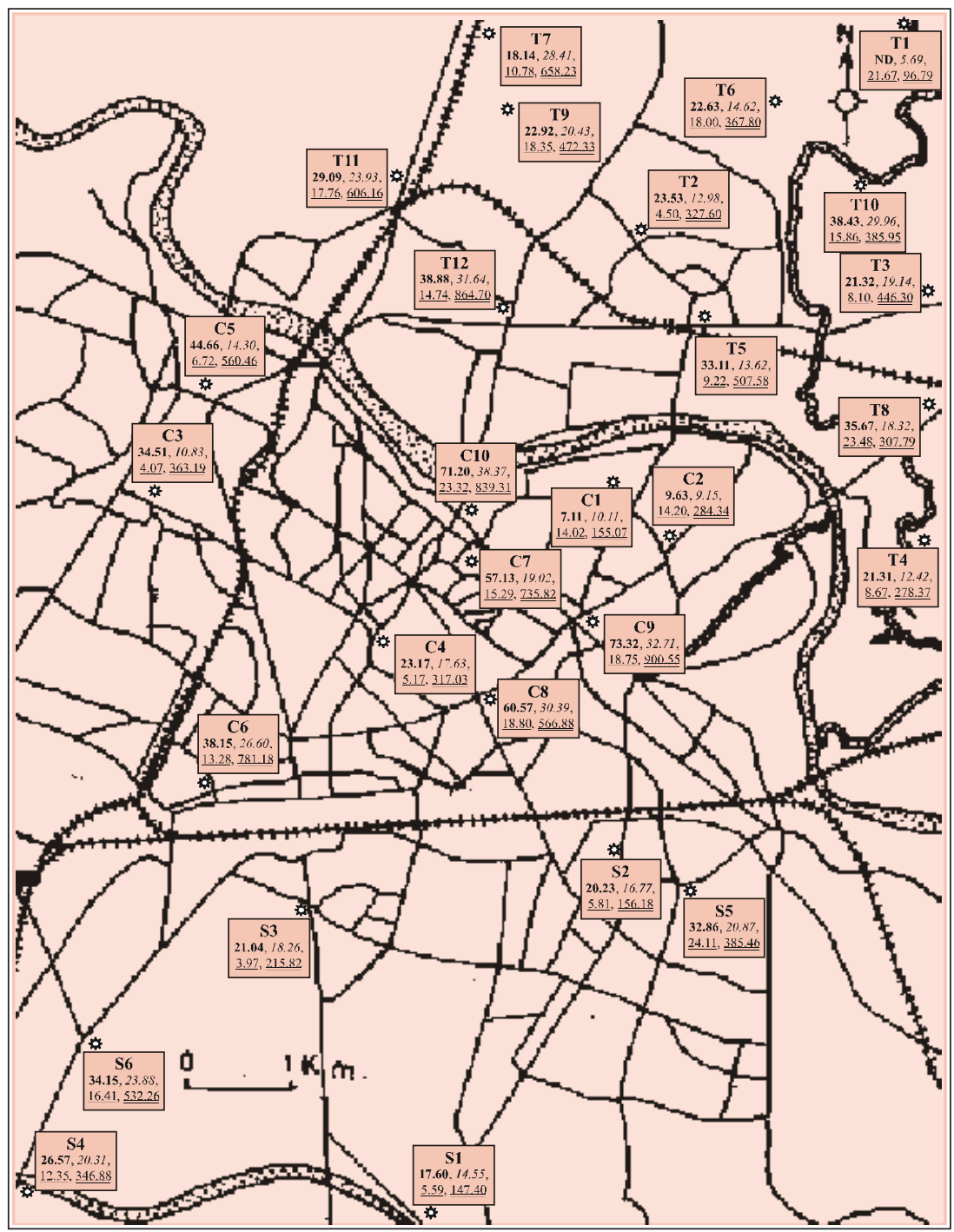

Fig. 1 A city map showing levels of different gaseous and particulate pollutants in different localities of the Lucknow city. (Values in bold, $\mathrm{SO}_{2}$; Italics, $\mathrm{NO}_{2}$; Single underline, $\mathrm{O}_{3}$ and double underline, SPM). 
or city. At any given time, the air shed is loaded with an array of gaseous and particulate pollutants emanating from the various sources. Hence, it becomes imperative to prepare an inventory of polluting sources in a particular region before air monitoring is carried out. The second step is to attenuate the pollution problem by using a suitable technology, engineering or chemical, to check emission of pollutants at source and later to filter out the pollutants from the atmosphere through biological means. Unlike engineering devices, biological devices are cost-effective, eco-friendly, self supporting and easy to maintain in the field conditions.

In this investigation, air monitoring of $\mathrm{SO}_{2}, \mathrm{NO}_{2}$, $\mathrm{O}_{3}$ and SPM levels showed a wide variation in their seasonal concentrations. The peak concentration of these pollutants, was generally observed during the winter season, followed by the summer season and the least in the rainy season. This was most probably due to the frequent thermal inversions and low wind speed particularly in the morning and night (foggy and wet environment) during the winter season, which checked the rapid dispersion of pollutants in the air (Samanta et al., 1998), However, during rainy season, the levels of all gaseous and particulate pollutants came down significantly due to the heavy and frequent rainfall that precipitated or washed out the ambient pollutants to get them either settled on the earth surface or deposited on the plant surface. In the summer season, high wind velocity accompanied with high temperature, facilitated the pollutant rapid dispersion in a large volume of air and thereby diluting their concentrations. However, the ozone level did not show any specific pattern with respect to seasonal changes. At many sites, it was observed that the concentration of $\mathrm{O}_{3}$ was maximum during the summer season and minimum during the winter season. It is likely that higher temperature in the summer season favoured $\mathrm{O}_{3}$ formation as a secondary pollutant. Massambani and Andrade (1994) also reported the ozone minima during the winter months and maxima during the summer. The 1989-1990 air monitor- ing data of Delhi also showed relatively low concentrations of $\mathrm{O}_{3}$ during the winter and high concentration during the summer (Varshney and Aggarwal, 1992).

On the basis of air pollution levels, the central region of the Lucknow city was found maximally polluted, while the southern region was found to be least polluted. The concentration of primary pollutants showed a positive correlation with the traffic density at almost all the sites, indicating that the traffic population is the main culprit of urban pollution. Automobiles are well known to cause air pollution along the roadsides (Rangarajan et al., 1995). Emission from major highways, based on an hourly vehicular count, was estimated using vehiclespecific emission factors. The vehicular density, the type of vehicles plying on the road, the road conditions, diffusion of the pollutants as affected by the topography of high rise buildings on the either side etc. are some of the major factors, affecting pollutant concentration on the roadside (Joshi, 1998). At some sites, it was also observed that although the vehicular traffic was low, but the pollution load was high. This was probably due to the poor road conditions and the high-rise buildings along the roadside, which impeded the dispersion of pollutants into the environment.

The AQI was developed to maintain consistency in reporting air quality within a city, state or through out the country. The AQI is so designed to make it easier to understand air quality from region to region. This system pays maximum emphasis on protecting the public health from air pollution. This tool is used to inform the residents of air pollution levels in a particular location and about its associated health effects and to advise precautionary steps to be taken when air pollution reaches alarming levels. Based on the principle that "prevention is better than the cure', it is possible to avoid pollution-related health hazards with the help of AQI data. The AQI scale ranges from 0 to 125 . The most important number of this scale is 50 . An AQI value in excess of 50 means that the ambient 


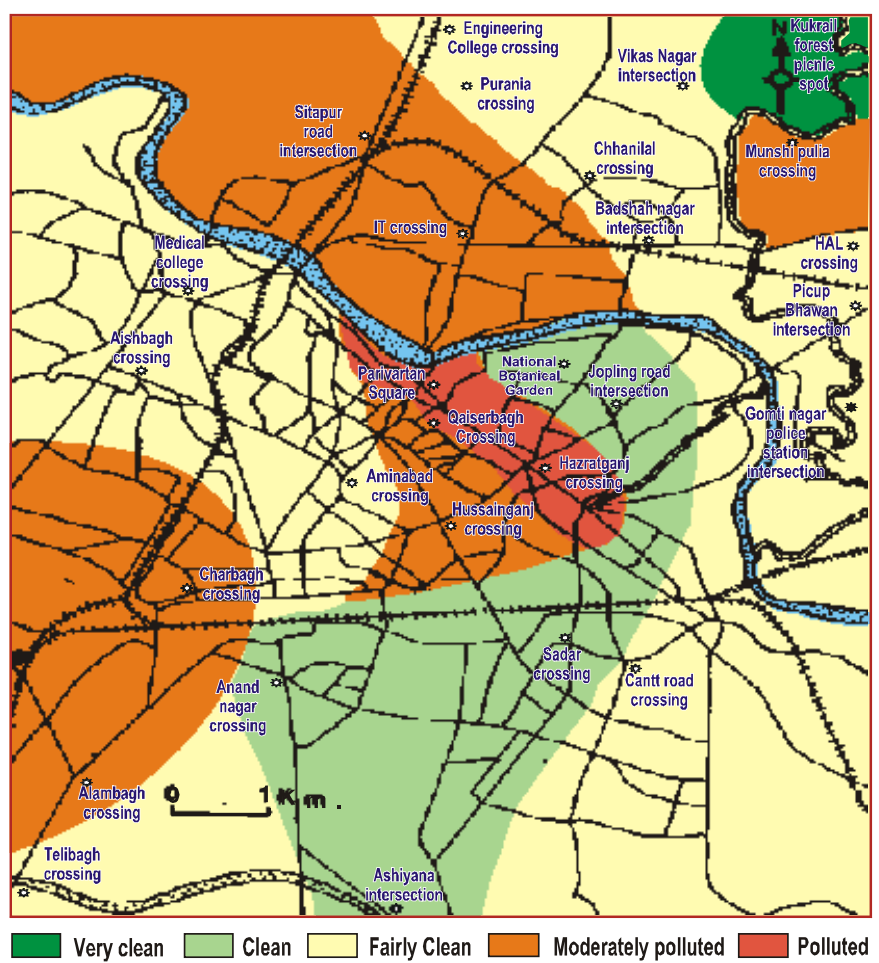

Fig. 2 Pollution map of the Lucknow city.

air concentration is reaching an alarming level in a locality. AQI levels above 100 may trigger immediate remedial actions by state and local officials to bring down pollution levels to save life. This could include health advisories to advice citizens or susceptible individuals to limit their certain activities.

On the basis of average air quality rating or index (AQI), for the first time, a city was zonated into different areas with varying degree of pollution level as reflected in the city map with different colour shades (Figure 2), which underlined the importance of $A Q I$ in pollution mapping of cities or industrial agglomerations. On the basis of above observations, it may be concluded that among three regions of the city adjudged on the basis of AQI, central region of the city was maximally polluted followed by trans-Gomti region and least was in the southern region. There was also seasonal variation in the levels of gaseous and particulate pollutants and hence the AQI being maximum in the winter season, followed by summer season and least pollution load and AQI values were noted in the rainy season. Based on AQI values, the air quality status of the different localities of the city varied between very clean and polluted category and finally we demonstrated that the AQI can also be used in pollution mapping programmes.

\section{Acknowledgements}

The authors wish to thank the Director, National Botanical Research Institute, Lucknow, India for providing necessary laboratory facilities. Amitosh Verma is grateful to the Council of Scientific and Industrial Research (CSIR), New Delhi, India for Senior Research Fellowship.

\section{References}

Agrawal, M., Singh, B., Rajput, M., Marshall, F., Bell, J.N.B., (2003) Effect of air pollution of peri-urban agriculture, a case study. Environ. Pollut., 126, 323-329. 
Aneja, Y.P., Agarwal, A., Roelle, P.A., Philips, S.B., Tong, Q., Nealson, W. and Yablonsky, R. (2001), Measurement and analysis of critical pollutants in New Delhi, India. Environ. Intl. 27, 35-42.

Byers, D.H. and Saltzman, B.E. (1958), Determination of ozone in air by natural and alkaline iodine procedure. Am. Ind. Hyg. Assoc. J. 19, 251-257.

Chaaban, F.B., Assi, R. and Abdo, J. 1995, A century of energy conversion: An environmental overview. Intl. J. Environ. Studies, 47, 133-142.

Cox, R.M. (2003), The use of passive sampling to monitor forest exposure to $\mathrm{O}_{3}, \mathrm{NO}_{2}$ and $\mathrm{SO}_{2}$, a review and some case studies. Environ. Pollut. 126, 301-311.

D'Amato, G. (1999), Out door pollution in urban areas and allergic respiratory diseases. Monaldi Arc. Chest Disease 54, 470-474.

Fuller, E.C. (1974), Chemistry and man's environment. Houghton Mifflin Company", Boston, pp. 502.

Gomez, K., Gomez, A.A. (1984), Statistical procedure for agricultural research" New York, John Willey and Sons.

Jacobs, M.B., Hochheiser, S. (1958), Continuous sampling and ultra micro-determination of nitrogen dioxide in air. Annals. Chem. 30, 426-428.

Joshi, G. (1998), Ambient air quality at road side of an urban area with special reference to respirable dust and total suspended particulate matter. Pollut. Res. 17(1), 79-81.
Massambani, O. and Andrade, F.(1994), Seasonal behavior of tropospheric ozone in the São Paulo (Brazil) metropolitan area. Atmos. Environ. 28, 3165-3169.

Mudri, S.S. (1999), Categorization of ambient air quality index. Ind. J. Environ. Prot. 10, 424-427.

Rangarajan, T.N., Arjunan, M.C. and Ponnammal, N.R. (1995), Effect of automobile pollution on few ornamental plants. Ecol. Environ. Conserv. 1, 1-4.

Samanta, G., Chattopadhyay, G., Mandal, B.K., Chowdhury, T.R., Chawdhury, P.P., Chanda, C.R., Banerjee, P., Lodh, D., Das, D. and Chakraborti, D. (1998), Air pollution in Calcutta during winter: A three year study. Curr. Sci. 75, 123-138.

Sivacoumar, R., Bhanarkar, A.D., Goyal, S.K., Galkari, S.K. and Aggarwal, A.L. (2001), Air pollution modeling for an industrial complex and model performance evaluation. Environ. Pollut. 111, 471-477.

Varshney, C.K. and Aggarwal, M. (1992), Ozone pollution in the urban atmosphere of Delhi. Atmos. Environ. 26, 291-294;

Verma, A., Singh, S.N. and Shukla, M.K. (2003), Air quality of the trans-Gomti area of Lucknow city, India. Bull. Environ. Contam. Toxicol. 70, 166-173.

West, P.D. and Gaeke, G.C. 1956, Fixation of sulfur dioxide as sulfitomercurate (II) and subsequent colorimetric estimation. Annals Chem. 28, 1816-1819. 